\title{
Purification and Properties of Cycloinulooligosaccharide Fructanotransferase from Paenibacillus polymyxa MG-CF6
}

\author{
(Received June 1, 2008; Accepted July 17, 2008) \\ Fumio Nanjo, ${ }^{1, *}$ Keiichi Goto, ${ }^{1}$ Hitomi Oka, ${ }^{2}$ Hisashi Muramatsu, ${ }^{2}$ \\ Shin-ichiro Kato ${ }^{3}$ and Shinji Nagata ${ }^{2}$ \\ ${ }^{1}$ Food Research Laboratories, Mitsui Norin Co., Ltd. (223-1, Miyabara, Fujieda 426-0133, Japan) \\ ${ }^{2}$ Laboratory of Applied Microbiology, Kochi University (Nankoku, Kochi 783-8502, Japan) \\ ${ }^{3}$ Science Research Center, Kochi University (Nankoku, Kochi 783-8502, Japan)
}

\begin{abstract}
A bacterial strain which produced a cycloinulooligosaccharide fructanotransferase was isolated from soil and was identified as Paenibacillus polymyxa MG-CF6. The enzyme was then purified to apparent homogeneity from culture supernatant of the bacterium. The molecular mass of the enzyme was estimated to be $128 \mathrm{kDa}$ by SDS-PAGE. Maximal activity was found to be at $\mathrm{pH} 7.0$ and $45^{\circ} \mathrm{C}$. The enzyme was stable from pH 6.0 to 9.0 and at temperature up to $40^{\circ} \mathrm{C}$. Molar ratio of cycloinulohexaose: cycloinuloheptaose formed by this enzyme was found to be about 2.5:1. $N$-Terminal amino acid sequence of the enzyme was identical with a part of amino acid sequence of the same enzymes from Bacillus macerans CFC1 and Bacillus polymyxa MGL 21. The gene of the enzyme was cloned from $P$. polymyxa MG-CF6. It consisted of 3999 nucleotides, which encodes a protein of 1333 amino acids. The deduced amino acid sequence showed 83,95 and $98 \%$ similarity to that of Bacillus circulans MCI-2554, Bacillus macerans CFC1 and Bacillus polymyxa MGL21, respectively.
\end{abstract}

Key words: cycloinulooligosaccharide fructanotransferase, cycloinulooligosaccharide, inulin, cyclofructan, Paenibacillus

Cycloinulooligosaccharide fructanotransferase (CFTase) was discovered in 1989 by Kawamura et al. ${ }^{1)}$ and was purified by Kawamura and Uchiyama. ${ }^{2)}$ This enzyme produces cycloinulooligosaccharides (CFs) from inulin, a linear $\beta$-(2-1)-linked polyfructofuranose chain having a terminal glucose residue. It has been reported that the CFs have the characteristic crown ether-like skeleton, ${ }^{3)}$ complexation properties with some metal ions, ${ }^{4)}$ and cryoprotective effects on the freeze-drying of liposome. ${ }^{5)}$ Thus, it is expected that CFs have a variety of function similar to cyclodextrins.

So far, it has been reported that only four bacteria, $B a$ cillus circulans OKUMZ 31B, ${ }^{1,2)}$ Bacillus circulans MCI$2554{ }^{6,7)}$ Paenibacillus (Bacillus) ${ }^{* *}$ macerans $\mathrm{CFC1}^{8,9)}$ and Paenibacillus (Bacillus) ${ }^{* *}$ polymyxa MGL21, ${ }^{10,11)}$ produce CFTase. These enzymes were purified and their enzymatic properties were characterized. We also found a bacterial strain MG-CF6 which produced CFTase during our studies on enzymatic conversion of inulin into oligosaccharides and monosaccharides.

In this study, we report on identification of the bacterial strain as Paenibacillus polymyxa MG-CF6 and on purification of a CFTase, and its enzymatic properties. In addition, we also describe determination of the CFTase gene.

\footnotetext{
*Corresponding author (Fax. +81-54-648-2001, E-mail: fnanjo@ mitsui-norin.co.jp).

Abbreviations: CFTase, cycloinulooligosaccharide fructanotransferase; CF, cycloinulooligosaccharide; CF6, cycloinulohexaose; $\mathrm{CF} 7$, cycloinuloheptaose.

** Genus of Bacillus macerans and Bacillus polymyxa has changed to genus Paenibacillus in taxonomy.
}

\section{MATERIALS AND METHODS}

Materials. Inulins from chicory roots, Jerusalem artichokes, and dahlia tuber were purchased from Sigma Co. (St. Louis, USA). Raftiline HP, which is spray-dried inulin prepared from chicory roots, was obtained from Orafti (Tienen, Belgium). Inulin (Fuji FF) which is produced from sucrose by a novel inulin-producing enzyme ${ }^{12)}$ was kindly supplied by Mr. M. Ohguchi, Fuji Nihon Seito Corporation (Shizuoka, Japan). Fructozyme L was purchased from Novozymes Japan Ltd. (Tokyo).

Cultivation. Cultivation medium composed of inulin $(40 \mathrm{~g} / \mathrm{L})$, yeast extract $(2 \mathrm{~g} / \mathrm{L}), \mathrm{NaNO}_{3}(5 \mathrm{~g} / \mathrm{L}), \mathrm{KH}_{2} \mathrm{PO}_{4}$ $(0.5 \mathrm{~g} / \mathrm{L}), \mathrm{MgSO}_{4} \cdot 7 \mathrm{H}_{2} \mathrm{O}(0.5 \mathrm{~g} / \mathrm{L}), \mathrm{KCl}(0.5 \mathrm{~g} / \mathrm{L}), \mathrm{FeCl}_{3}$ $(10 \mathrm{mg} / \mathrm{L})$, and $\mathrm{CaCO}_{3}(1 \mathrm{~g} / \mathrm{L})$, in tap water $(\mathrm{pH} 7.0)$. The microorganism was cultivated at $35^{\circ} \mathrm{C}$ for $72 \mathrm{~h}$ on a rotary shaker $(200 \mathrm{rpm})$.

Identification of Microorganism. Taxonomic characteristics of the bacterial strain MG-CF6 capable of producing CFTase were examined on the basis of Bergey's manual of systematic bacteriology. ${ }^{13)}$ The $16 \mathrm{~S}$ rDNA sequence of the bacterium was also determined according to our method described previously. ${ }^{14)}$ Then, the 16S rDNA sequence determined was compared using the DNA data bank of Japan and the bacterium was identified.

Preparation of Cycloinulooligosaccharides. The microorganism was cultivated as described above and then culture broth (about $700 \mathrm{~mL}$ ) was centrifuged at 18,500 $\times g$ for $10 \mathrm{~min}$ at $4^{\circ} \mathrm{C}$. Solid ammonium sulfate was added to the supernatant to obtain $80 \%$ saturation. After standing overnight at $4^{\circ} \mathrm{C}$, the precipitate was collected by 
centrifugation and dissolved in about $10 \mathrm{~mL}$ of $10 \mathrm{mM}$ sodium phosphate buffer ( $\mathrm{pH}$ 7.0). The enzyme solution was then dialyzed with $1000 \mathrm{~mL}$ of the same phosphate buffer for $24 \mathrm{~h}$ at $4{ }^{\circ} \mathrm{C}$. The dialyzed solution was used as the crude enzyme preparation. This crude enzyme solution (3 mL) was added to $200 \mathrm{~mL}$ of $10 \%$ inulin (from chicory) solution and the mixture was incubated at $35^{\circ} \mathrm{C}$ for $60 \mathrm{~h}$. To the reaction mixture was added Fructozyme L (800 U, Novozymes Japan Ltd.) containing both endoand exo-inulinase, and was incubated for $1 \mathrm{~h}$ at $60^{\circ} \mathrm{C}$. The solution was heated for $10 \mathrm{~min}$ in a boiling water bath. The reaction mixture was applied to a column $(\phi 44 \times 475$ $\mathrm{mm}, 720 \mathrm{~mL}$ ) of charcoal-Celite which had been equilibrated with distilled water. The column was washed with $3000 \mathrm{~mL}$ of distilled water and then eluted with $2100 \mathrm{~mL}$ of $30 \%$ ethanol solution. The effluent was evaporated and lyophilized to give $8.3 \mathrm{~g}$ of mixture containing two major compounds 1 and 2 by HPLC analysis as described below. The compounds 1 and 2 were isolated by QAEToyopearl 550C chromatography as reported by Kawamura et al. ${ }^{1)}$ The compound 1 was crystallized from ethanol in spite of methanol by the method of Kushibe et al., ${ }^{6}$ giving a yield of $5.1 \mathrm{~g}$. The compound 2 was further purified by gel-filtration using Toyopearl HW-40S column $(\phi 50 \times 950 \mathrm{~mm}, 1800 \mathrm{~mL})$ and the lyophilized powder of compound $2(1.9 \mathrm{~g})$ was finally obtained.

The compounds 1 and 2 showed almost the same ${ }^{1} \mathrm{H}$ and ${ }^{13} \mathrm{C}$-NMR spectra and ${ }^{13} \mathrm{C}-\mathrm{NMR}$ spectra of the two compounds were superimposed on those of cycloinulohexaose (CF6) previously reported. ${ }^{1)}$ The positive FABMS spectrum of the compound 1 showed a protonated, molecular ion peak at $m / z=973[\mathrm{M}+\mathrm{H}]^{+}$and therefore was identified as CF6. In the case of compound 2, a protonated molecular ion peak at $m / z \quad 1135[\mathrm{M}+\mathrm{H}]^{+}$was obtained by the FAB-MS. Accordingly, the compound 2 was identified as cycloinuloheptaose (CF7), and was also confirmed by elementary analysis (Calcd. for $\mathrm{C}_{42} \mathrm{H}_{70} \mathrm{O}_{35} 3 \mathrm{H}_{2} \mathrm{O}$ : C, 42.43; H, 6.44. Found: C, 42.50; H, 6.73).

Analytical Methods. CFs were analyzed by a Waters HPLC system (Waters 2690) equipped with a Shodex RI101 detector under two conditions as below: (A) column, MCI GEL CK04SS $(\phi 10 \times 200 \mathrm{~mm}$, Mitsubishi Chemical Co.); mobile phase, distilled water; column temperature, $60^{\circ} \mathrm{C}$; flow rate; $0.3 \mathrm{~mL} / \mathrm{min}$. (B) column, Shodex AsahiPak NH2P-504E $(\phi 4.6 \times 250 \mathrm{~mm}$, Showa Denko K.K.); mobile phase, acetonitrile/water $(3 / 1, \mathrm{v} / \mathrm{v})$; column temperature, room temperature; flow rate, $0.8 \mathrm{~mL} / \mathrm{min}$. NMR spectra were recorded on a JEOL JNM-GSX500M system. Samples $(10 \mathrm{mg})$ were dissolved in $0.5 \mathrm{~mL}$ of $\mathrm{D}_{2} \mathrm{O}$. FAB-MS analysis was carried out by a JEOL JMS DX303 system. Elementary analysis was performed at Microanalytica Narita in Shizuoka, Japan.

CFTase activity. A reaction mixture $(1 \mathrm{~mL})$ containing $2 \%$ inulin (chicory roots) and an enzyme solution in $40 \mathrm{~mm}$ sodium phosphate buffer $(\mathrm{pH}$ 7.0) were incubated for $60 \mathrm{~min}$ at $40^{\circ} \mathrm{C}$. The reaction was stopped by heating for $5 \mathrm{~min}$ in a boiling water bath. Then, CFs were determined by HPLC under the conditions $\mathrm{A}$ as stated above, with CF6 and CF7 as standards. One unit of CFTase activity was defined as the amount of enzyme that formed 1 micromole of CFs (CF6+CF7) per min.
Preparation of Cycloinulohexaose-Sepharose CL-6B. Cyanogen bromide-activated Sepharose CL-6B (25 mL) prepared according to the method of March et al. ${ }^{15)}$ was suspended in $50 \mathrm{~mL}$ of $0.5 \mathrm{M}$ 1,6-hexane diamine $(\mathrm{pH}$ 10.0) and shaken for $5 \mathrm{~h}$ at room temperature. The resulting aminohexyl(AH)-Sepharose was washed with $150 \mathrm{~mL}$ each of the following: $1 \mathrm{M} \mathrm{NaHCO}$ containing $0.5 \mathrm{M}$ $\mathrm{NaCl}$, distilled water, $1 \mathrm{~N} \mathrm{HCl}$, distilled water, $1 \mathrm{~N} \mathrm{NaOH}$ and finally distilled water. Next, cyanogen bromideactivated CF6 was prepared by reacting $50 \mathrm{~mL}$ of $1 \mathrm{M}$ $\mathrm{NaHCO}_{3}$ containing $2.5 \mathrm{~g}$ of CF6 with $5 \mathrm{~mL}$ of acetonitrile containing $2.5 \mathrm{~g}$ of cyanogen bromide for $3 \mathrm{~min}$ at $4^{\circ} \mathrm{C}$. To the reaction mixture was added the $\mathrm{AH}$ Sepharose and the suspension was shaken for $18 \mathrm{~h}$ at $4^{\circ} \mathrm{C}$. The resultant gel was washed successively with $1 \mathrm{M} \mathrm{Na}-$ $\mathrm{HCO}_{3}, 1 \mathrm{M} \mathrm{KCl}, 1 \mathrm{M}$ sodium acetate and distilled water (250 $\mathrm{mL}$, respectively). The CF6-Sepharose CL-6B thus prepared was stored in $0.05 \%$ sodium azide solution at $4^{\circ} \mathrm{C}$ until use.

Purification of CFTase. Unless otherwise indicated, all operations for the enzyme purification were carried out at $0-4^{\circ} \mathrm{C}$.

Step 1: Ammonium sulfate fractionation. After cultivation of the microorganism, the cells were removed from the culture broth by centrifugation at $18,500 \times g$ for $20 \mathrm{~min}$. Solid ammonium sulfate was added to the supernatant $(780 \mathrm{~mL})$ to obtain $80 \%$ saturation. After standing overnight, the precipitate was collected by centrifugation and then dissolved in $8.5 \mathrm{~mL}$ of $50 \mathrm{mM}$ Tris- $\mathrm{HCl}$ buffer (pH 7.0). The solution was passed through a Sephadex G25 column $(\phi 26 \times 550 \mathrm{~mm})$ previously equilibrated with the same buffer. Elution patterns were monitored by a Pharmacia UV-2 monitor.

Step 2: DEAE-Toyopearl 650 M chromatography. The eluate $(92 \mathrm{~mL})$ obtained at step 1 was applied to a column $(\phi 25 \times 180 \mathrm{~mm})$ of DEAE-Toyopearl $650 \mathrm{M}$ which had been equilibrated with $50 \mathrm{mM}$ Tris- $\mathrm{HCl}$ buffer $(\mathrm{pH}$ 7.0). The column was washed with $450 \mathrm{~mL}$ of the above buffer and then eluted with a $1000 \mathrm{~mL}$ linear gradient of 0 to $0.25 \mathrm{M} \mathrm{NaCl}$ in the same Tris- $\mathrm{HCl}$ buffer at a flow rate of $115 \mathrm{~mL} / \mathrm{h}$ and $17-\mathrm{mL}$ fractions were collected. The fractions $(216 \mathrm{~mL})$ containing enzyme activity was collected and concentrated to $20 \mathrm{~mL}$ with a Centriplus YM-30 ultrafiltration membrane (Millipore Co.).

Step 3: Affinity chromatography on CF6-Sepharose CL-6B. The enzyme solution obtained from step 2 was applied to CF6-Sepharose CL-6B column $(\phi 14 \times 83 \mathrm{~mm})$ previously equilibrated with $50 \mathrm{~mm}$ Tris- $\mathrm{HCl}$ buffer $(\mathrm{pH}$ 7.0). After washings with $80 \mathrm{~mL}$ of the same buffer, the enzyme was eluted with the buffer containing $0.5 \%$ inulin (chicory roots) at a flow rate of $20 \mathrm{~mL} / \mathrm{h}$ and $2-\mathrm{mL}$ fractions were collected. The fractions $(32 \mathrm{~mL})$ having enzyme activity was pooled and then concentrated to 1.4 $\mathrm{mL}$ by the ultrafiltration as mentioned in step 2 .

Step 4: Gel-filtration on Superdex 200. The enzyme solution obtained from step 3 was applied to Superdex 200 prep column $(\phi 16 \times 760 \mathrm{~mm})$ previously equilibrated with $50 \mathrm{~mm}$ Tris- $\mathrm{HCl}$ buffer ( $\mathrm{pH}$ 7.0). The resulting effluent was re-circulated back onto the column at a flow rate of $20 \mathrm{~mL} / \mathrm{h}$ and this re-circulation was repeated 5 times. Elution profile was monitored by the Pharmacia UV-2 
monitor during the re-circulation. Then, the column was eluted with $50 \mathrm{mM}$ Tris- $\mathrm{HCl}$ buffer $(\mathrm{pH} \mathrm{7.0)}$ and $1.5-\mathrm{mL}$ fractions were collected. The fractions $(14 \mathrm{~mL})$ containing enzyme activity were pooled and concentrated to $1.3 \mathrm{~mL}$ by the ultrafiltration with a Centriplus YM-30.

Analytical methods for enzyme. Protein was determined by the method of Lowry et al. ${ }^{16)}$ with bovine serum albumin as a standard. Polyacrylamide gel electrophoresis was performed by a Phastsystem (Amersham Pharmacia Biotech Ltd.). The purity and relative molecular mass of the enzyme were examined by SDS-PAGE using $7.5 \%$ gel (PhastGel Homogeneous 7.5), with a HMW SDS Marker Kit (Amersham Pharmacia Biotech Ltd.) as molecular markers. Gels were stained with Coomassie Brilliant Blue G-250. Estimation of the molecular mass by gel-filtration was carried out by a Waters HPLC system (Waters 2690) equipped with TSK-GEL SUPER SW $3000(\phi 4.6 \times 300$ $\mathrm{mm}$, Tosoh Co.). The column was eluted with $0.1 \mathrm{M}$ sodium phosphate buffer $(\mathrm{pH} 7.0)$ containing $0.1 \mathrm{M}$ sodium sulfate and $0.025 \%$ sodium azide at a flow rate of 0.3 $\mathrm{mL} / \mathrm{min}$ at room temperature with a Gel Filtration Molecular Markers (Sigma), and the elution profile was monitored by a Waters UV detector (Waters 2487) at 280 nm. $N$-Terminal amino acid sequence of the enzyme was analyzed on a Shimadzu PPSQ-10 Protein Peptide Sequencer at Shizuoka University, Japan. Comparison of the sequence with other protein sequences was performed using a FASTA data base.

Nucleotide sequence of CFTase gene (cft). Chromosomal DNA was prepared from $P$. polymyxa MG-CF6 by the method of Saito and Miura. ${ }^{17)}$ A core sequence of $c f t$ was amplified from the DNA by polymerase chain reaction (PCR). Primers used were designed on the basis of the $N$-terminal amino acid sequence of the CFTase and the nucleotide sequences which are highly conserved regions of three CFTase gene previously reported. ${ }^{10,18,19)}$ Furthermore, to determine the upstream and the downstream sides of the core sequence inverse PCR was done. These nucleotides of resultant PCR products were sequenced with an Applied Biosystems 373A DNA sequencer and a DNA sequencing kit (ABI PRISM Dye Terminator Cycle Sequencing Ready Reaction Kit). The nucleotide sequence of the CFTase was assigned DDBJ accession no. AB 379660.

Cloning and expression of the CFTase gene from $P$. polymyxa MG-CF6 in Escherichia coli. A DNA fragment containing the CFTase gene was amplified by PCR with Ex Taq DNA polymerase (Takara Bio Inc., Kyoto, Japan) and with sense primer containing a EcoRI site, the Shine-Dalgarno (SD) sequence, and the ATG start codon (5'-GGGAATTCAGGAAACAGACCATGGATATCAAG CCGGATTTCAAGCG-3') and an antisense primer containing a Pst I site (5'-GGCTGCAGTCAGTTGTTGTTTT CTTCTTTACCTGAACAGG-3'). The sense primer was designed on the basis of the $N$-terminal amino acid sequence of the CFTase from $P$. polymyxa MG-CF6. Furthermore, to obtain the CFTase containing $N$-terminal amino acid sequence corresponding to that of the CFTase from Bacillus macerans CFC1, a DNA fragment was amplified with sense primer containing a EcoRI site, the SD sequence, the ATG start codon (5'-GGGAATTCAGGAA
ACAGACCATGTTCCCCAAGCAAGTGGTAAGGGTA C-3') and the same antisense primer as mentioned above. Each of the two amplified DNA fragments (122 and 108 $\mathrm{kDa}$ enzymes) was ligated into the EcoRI-Pst I site of pUC18. The resultant plasmids, pCFTASE-122 and pCFTASE-108, were introduced into E. coli JM109 to provide recombinant $122 \mathrm{kDa}$ and $108 \mathrm{kDa}$ CFTase. E. coli JM109 carrying the each pCFTASE was cultured in LB medium containing $50 \mu \mathrm{g} / \mathrm{mL}$ ampicillin and $200 \mu \mathrm{g} /$ $\mathrm{mL}$ isopropyl- $\beta$-D-thiogalactopyranoside (IPTG) at $37^{\circ} \mathrm{C}$ for overnight.

\section{RESULTS}

\section{Identification of microorganism.}

A strain MG-CF6 that produces CFs from inulin was classified as Paenibacillus polymyxa from taxonomic characteristics as shown in Table 1. DNA-DNA hybridization value between type strain of Paenibacillus polymyxa and the strain MG-CF6 was found to be $85 \%$. In addition, comparative sequence analysis of $16 \mathrm{~S}$ rDNA between the strain MG-CF6 and the type strain revealed that the strain MG-CF6 possessed $100 \%$ sequence similarity to the type strain. As a result, the strain was identified as Paenibacillus polymyxa MG-CF6.

\section{Purification of CFTase.}

A summary of the specific activity and recovery of the enzyme during the purification procedure based on 780 $\mathrm{mL}$ of the culture supernatant is given in Table 2 . The enzyme was purified 500 -fold with a yield of about $22 \%$. In the purification procedure, affinity chromatography on the CF6-Sepharose was very effective for purification of the enzyme. The purified CFTase showed a single protein band on SDS-PAGE (Fig. 1). The molecular mass of the enzyme was estimated to be $128 \mathrm{kDa}$ by SDS-PAGE and $118 \mathrm{kDa}$ by gel filtration method. The isoelectric point of the enzyme was estimated to be around $\mathrm{pH} 5.1$ and the enzyme was microheterogeneous (data not shown).

\section{General properties.}

General properties of the purified CFTase are summarized in Table 3. Optimum $\mathrm{PH}$ of the CFTase activity was measured in McIlvaine buffer $(\mathrm{pH} 3.0-8.0)$ and in $0.1 \mathrm{M}$ borate- $\mathrm{NaOH}$ buffer $(\mathrm{pH} 8.0-10.0)$ in the presence of $2 \%$ inulin at $40^{\circ} \mathrm{C}$. The enzyme showed a maximum activity at $\mathrm{pH} 7.0$ and retained more than $80 \%$ of its maximum activity in the range of $\mathrm{pH} 6.0$ to 8.0 . The $\mathrm{pH}$ stability of the enzyme was examined by incubation of the enzyme for $18 \mathrm{~h}$ at $4{ }^{\circ} \mathrm{C}$ in the respective buffers (ranging from $\mathrm{pH}$ 3.0 to 10.0 ) prior to assay at its optimum $\mathrm{pH}$. The enzyme was stable in the range of $\mathrm{pH} 6.0$ to 9.0. Optimum temperature of the enzyme was determined by measuring under the standard conditions and varying temperatures from 30 to $70^{\circ} \mathrm{C}$. The enzyme showed its maximum activity at $45^{\circ} \mathrm{C}$ and more than $80 \%$ of its maximum activity was observed between 40 and $50^{\circ} \mathrm{C}$. After incubation of the enzyme at different temperatures for $30 \mathrm{~min}$, the enzyme activity was measured under standard conditions. The enzyme was stable up to $40^{\circ} \mathrm{C}$ and lost its activity at $60^{\circ} \mathrm{C}$. The CFTase was completely inhibited by $1 \mathrm{mM} \mathrm{Ag}^{+}$ion 
Table 1. Taxonomic characteristics of Paenibacillus polymyxa MG-CF6.

\begin{tabular}{|c|c|c|}
\hline Characteristics & Type strain & MG-CF6 \\
\hline Gram reaction & - & - \\
\hline Motility & + & + \\
\hline $\begin{array}{l}\text { Length of rod } \\
\text { (micro meter) }\end{array}$ & ND & $2.8-3.5$ \\
\hline $\begin{array}{l}\text { Diameter of rod } \\
\text { (micro meter) }\end{array}$ & ND & $1.7-2.4$ \\
\hline $\begin{array}{l}\text { Spore position and } \\
\text { shape }\end{array}$ & $\begin{array}{l}\text { Center, } \\
\text { ellipsoidal }\end{array}$ & $\begin{array}{l}\text { Center, } \\
\text { ellipsoidal }\end{array}$ \\
\hline Sporangium swollen & + & NT \\
\hline \multicolumn{3}{|l|}{ Growth at } \\
\hline $10^{\circ} \mathrm{C}$ & + & - \\
\hline $30^{\circ} \mathrm{C}$ & + & + \\
\hline $40^{\circ} \mathrm{C}$ & + & + \\
\hline $50^{\circ} \mathrm{C}$ & - & - \\
\hline Catalase & + & + \\
\hline \multicolumn{3}{|l|}{ Growth in the presence of } \\
\hline $2 \% \mathrm{NaCl}$ & ND & + \\
\hline $5 \% \mathrm{NaCl}$ & - & - \\
\hline $7 \% \mathrm{NaCl}$ & - & - \\
\hline $10 \% \mathrm{NaCl}$ & - & - \\
\hline Anaerobic growth & + & + \\
\hline \multicolumn{3}{|l|}{ Acid from } \\
\hline Glucose & + & + \\
\hline Cellobiose & + & + \\
\hline Galactose & + & + \\
\hline Mannose & + & + \\
\hline Melibiose & + & + \\
\hline Raffinose & + & + \\
\hline Salicin & + & + \\
\hline Xylose & + & + \\
\hline Lactose & - & + \\
\hline Starch & + & + \\
\hline Inulin & + & + \\
\hline L-Rhamnose & - & - \\
\hline Sorbitol & - & - \\
\hline L-Sorbose & - & - \\
\hline Adonitol & - & - \\
\hline Gas from glucose & + & + \\
\hline Utilization of citrate & - & - \\
\hline Urease & - & - \\
\hline Production of indole & - & - \\
\hline Voges-Proskauer test & + & + \\
\hline Egg-york reaction & - & - \\
\hline Nitrate reduced to nitrite & + & - \\
\hline Tyrosine degradation & - & - \\
\hline Gelatin hydrolysis & + & + \\
\hline Starch hydrolysis & + & + \\
\hline Oxidase & - & - \\
\hline Lysozyme resistance & + & + \\
\hline Major fatty acid & $\begin{array}{c}\text { Anteiso-C15:0, } \\
\text { C16:0 }\end{array}$ & $\begin{array}{c}\text { Anteiso-C15:0, } \\
\text { C16:0 }\end{array}$ \\
\hline GC content $(\mathrm{mol} \%)$ & $44.3-45.6$ & 48.05 \\
\hline Murein type & Meso-DAP direct & meso-DAP \\
\hline Main menaquinone & MK-7 & MK-7 \\
\hline
\end{tabular}

Meso-DAP, meso-diaminopimelic acid; MK-7, menaquinone 7; ND, not data available; NT, not tested.
(Table 4). The enzyme produced a mixture of CF6 and CF7, which had a molar ratio of about 5:2. The CFTase activity were examined with inulins derived from different sources (Table 5). The CFTase showed the highest activity toward inulin from chicory roots and the CFTase activities on the other inulins remained more than $90 \%$

Table 2. Purification of cycloinulooligosaccharide fructanotransferase from Paenibacillus polymyxa MG-CF6.

\begin{tabular}{lccccc}
\hline \multicolumn{1}{c}{ Steps } & $\begin{array}{c}\text { Total } \\
\text { protein } \\
(\mathrm{mg})\end{array}$ & $\begin{array}{c}\text { Total } \\
\text { activity } \\
(\mathrm{U})\end{array}$ & $\begin{array}{c}\text { Specific } \\
\text { activity } \\
(\mathrm{U} / \mathrm{mg})\end{array}$ & $\begin{array}{c}\text { Yield } \\
(\%)\end{array}$ & $\begin{array}{c}\text { Purifi- } \\
\text { cation } \\
\text { (fold) }\end{array}$ \\
\hline Culture & 430 & 120 & 0.28 & 100 & 1.0 \\
$\left(\mathrm{NH}_{4}\right)_{2} \mathrm{SO}_{4}$ fraction & 93 & 88 & 0.95 & 73 & 3.4 \\
DEAE-Toyopearl & 11 & 80 & 7.3 & 67 & 26 \\
CF6-Sepharose & 0.27 & 38 & 140 & 32 & 500 \\
Superdex 200 & 0.18 & 26 & 140 & 22 & 500 \\
\hline
\end{tabular}

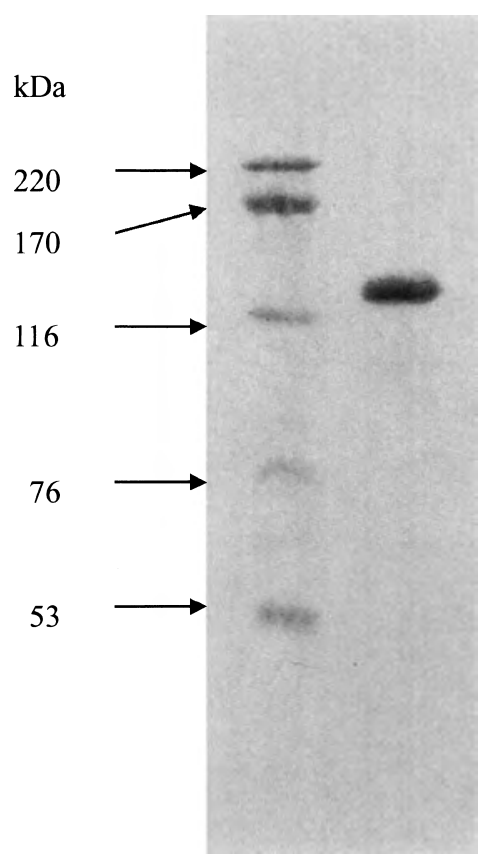

Fig. 1. SDS-PAGE of purified enzyme.

Right line, purified enzyme; left line, protein molecular mass markers; myosin from rabbit muscle $(220 \mathrm{kDa}), \alpha$-2-macroglobulin from bovine plasma $(170 \mathrm{kDa}), \beta$-galactosidase from E. coli $(116$ $\mathrm{kDa})$, transferrin from human $(76 \mathrm{kDa})$, glutamate dehydrogenase from bovine liver $(53 \mathrm{kDa})$.

Table 3. Comparison of general properties of purified CFTase with other CFTase previously reported.

\begin{tabular}{|c|c|c|c|c|c|c|}
\hline \multirow[b]{2}{*}{ Characteristics } & \multicolumn{6}{|c|}{ CFTase } \\
\hline & $\begin{array}{l}\text { P. polymyxa } \\
\text { MG-CF6 }\end{array}$ & $\begin{array}{l}P \text {. polymyxa } \\
\text { MGL21 }\end{array}$ & $\begin{array}{l}P . \text { polymyxa } \\
\text { MGL21 }\end{array}$ & $\begin{array}{l}\text { P. macerans } \\
\text { CFC } 1\end{array}$ & $\begin{array}{l}\text { B. circulans } \\
\text { MCI-2554 }\end{array}$ & $\begin{array}{l}\text { B. circulans } \\
\text { OKUMZ31B }\end{array}$ \\
\hline Molecular mass (kDa) & 128 & 148 & 108 & 110 & 115 & 132 \\
\hline Optimum pH & $7.0^{\mathrm{a})}$ & 9.0 & 7.0 & 7.5 & 7.5 & 7.5 \\
\hline pH Stability & $6.0-9.0^{\mathrm{b})}$ & $7.0-10.0$ & - & $6.0-9.5$ & $5.5-9.5$ & $6.0-9.0$ \\
\hline Optimum temperature $\left({ }^{\circ} \mathrm{C}\right)$ & $45^{\mathrm{c})}$ & 50 & 40 & 45 & 45 & 45 \\
\hline Thermal stability $\left({ }^{\circ} \mathrm{C}\right)$ & Below $40^{\text {c) }}$ & Be1ow 50 & - & Below 45 & Below 45 & Below 40 \\
\hline Inhibition of metal ion & $\mathrm{Ag}^{+\mathrm{d})}$ & $\mathrm{Ag}^{+}, \mathrm{Cu}^{2+}$ & $\mathrm{Ag}^{+}$ & $\mathrm{Ag}^{+}, \mathrm{Cu}^{2+}$ & $\mathrm{Fe}^{2+}, \mathrm{Cu}^{2+}$ & $\mathrm{Hg}^{2+}$ \\
\hline Production ratio of CF6: CF7 & $2.5: 1$ & $2.7: 1^{\mathrm{e})}$ & $2.7: 1^{\mathrm{e})}$ & 4.0:1 & 4.0:1 & 4.0:1 \\
\hline
\end{tabular}

${ }^{a}$ Optimum $\mathrm{pH}$ of the purified enzyme was measured in Mcllvain buffer ( $\mathrm{pH} 3.0-8.0$ ) and in $0.1 \mathrm{M}$ borate- $\mathrm{NaOH}$ buffer ( $\mathrm{pH} 8.0-10.0$ ) in the presence of $2 \%$ inulin. ${ }^{\mathrm{b})}$ For measurement of $\mathrm{pH}$ stability, the enzyme was incubated in the above buffers for $18 \mathrm{~h}$ at $4{ }^{\circ} \mathrm{C}$ and then the remaining activity was assayed in $0.2 \mathrm{M}$ sodium phosphate buffer, $\mathrm{pH} 7.0$ in the presence of $2 \%$ inulin. ${ }^{\mathrm{c}} \mathrm{Optimum}$ temperature was measured at different temperature of $30-70^{\circ} \mathrm{C}$ according to the assay method described in MATERIALS AND METHODS. For measurement of thermal stability, the enzyme was incubated at the different temperatures for $30 \mathrm{~min}$ and then the activity was assayed. ${ }^{\mathrm{d}}$ For examining the effects of metal ions, the enzyme activity was measured under optimum conditions in the presence of 1 mM metal ions. ${ }^{\text {e) }}$ The ratio is obtained with crude enzyme from $P$. polymyxa MGL21. ${ }^{10}$ 
Table 4. Effects of metal ions on CFTase activity.

\begin{tabular}{lc}
\hline Metal ions & $\begin{array}{c}\text { Relative activity } \\
(\%)\end{array}$ \\
\hline None & 100 \\
$\mathrm{Na}^{+}$ & 102 \\
$\mathrm{Ag}^{+}$ & 0 \\
$\mathrm{Ca}^{2+}$ & 107 \\
$\mathrm{Co}^{2+}$ & 102 \\
$\mathrm{Cu}^{2+}$ & 100 \\
$\mathrm{Fe}^{2+}$ & 96 \\
$\mathrm{Mg}^{2+}$ & 103 \\
$\mathrm{Zn}^{2+}$ & 100 \\
$\mathrm{Al}^{3+}$ & 82 \\
$\mathrm{Fe}^{3+}$ & 100 \\
$\mathrm{EDTA}$ & 94 \\
\hline
\end{tabular}

The enzyme activity was assayed under optimum conditions in the presence of $1 \mathrm{mM}$ metal ions.

compared with those on the chicory inulin.

\section{$N$-Terminal amino acid sequence.}

$\mathrm{N}$-Terminal amino acid sequence was determined up to 14 residues and was compared with other CFTase reported so far (Table 6). The $N$-terminal sequence was fully consistent with the amino acid sequence of 253 to 266 from Bacillus macerans $\mathrm{CFC1}^{19)}$ and Paenibacillus polymyxa MGL21 ${ }^{10)}$ enzymes and also possessed about $78.5 \%$ similarity to the amino acid sequence (235-248) of CFTase from Bacillus circulans MCI-2554. ${ }^{18)}$

\section{DNA sequence and deduced amino acid sequence.}

The entire open reading frame of $c f t$ consists of 3999 nucleotides encoding a protein of 1333 amino acids with a predicted molecular mass of $149,461 \mathrm{Da}$, as shown in Fig. 2. $N$-Terminal amino acid sequence (DIKPDFKRYEI DNP) of the purified CFTase was found in amino acid residues 253-266 of the deduced amino acid sequence. The molecular mass of the purified enzyme is estimated to be $121,942 \mathrm{Da}$, accordingly. The deduced amino acid sequence of the CFTase from $P$. polymyxa MG-CF6 showed 83, 95 and 98\% similarity to that of Bacillus circulans MCI-2554, ${ }^{18)}$ Paenibacillus (Bacillus) macerans CFC1, ${ }^{19)}$ and Paenibacillus (Bacillus) polymyxa MGL21, ${ }^{10)}$ respectively, as illustrated in Fig. 3.

\section{Enzyme assay of the recombinant CFTase.}

Cultured E. coli cells expressing 122 and $108 \mathrm{kDa}$ CFTase were disrupted by sonication and centrifuged. The CFTase activities in the resultant crude extract were 0.22 $\mathrm{U} / \mathrm{mg}$ for $122 \mathrm{kDa}$ enzyme and $0.07 \mathrm{U} / \mathrm{mg}$ for $108 \mathrm{kDa}$ enzyme, whereas the crude extract of E. coli JM109 carrying pUC18 was inert.

\section{DISCUSSION}

There have been only four reports concerning the purification and characterization of CFTase ${ }^{2,7,9,10)}$ up until now. We purified and characterized the CFTase from Paenibacillus polymyxa MG-CF6 and its general properties are summarized in comparison with the other five CFTases (Table 3). Optimal PH (7.0) of the enzyme was different from that $(\mathrm{pH} 7.5)$ of the enzymes from B. macerans
Table 5. Effects of inulins from different sources on CFTase activity.

\begin{tabular}{lc}
\hline \multicolumn{1}{c}{ Inulin from } & Relative activity $(\%)$ \\
\hline Chycory roots & 100 \\
Jerusalem artichokes & 99 \\
Dahlia tuber & 92 \\
Rafterin HP & 95 \\
Fuji FF & 94 \\
\hline
\end{tabular}

The enzyme activity was measured under optimum conditions in the presence of $2 \%$ each inulin.

Table 6. Comparison of $N$-terminal amino acid sequences from the purified CFTase with peptides of CFTase from other origin.

\begin{tabular}{ll}
\hline \multicolumn{1}{c}{ CFTase from } & \multicolumn{1}{c}{ Amino acid sequence } \\
\hline P. polymyxa MG-CF6 & DIKPDFKRYEIDNP $(N$-terminal $)$ \\
P. polymyxa MGL21 & DIKPDFKRYEIDNP $(253-266)$ \\
B. macerans CFC1 & DIKPDFKRYEIDNP $(253-266)$ \\
B. circulans MCI-2554 & DIKPDFERYQIENP $(235-248)$ \\
\hline
\end{tabular}

CFC1, B. circulans OKUMZ31B and B. circulans MCI2554. The optimal $\mathrm{pH}$ of the enzyme was also distinct from that $(\mathrm{pH} 9.0)$ of the recombinant CFTase (148 kDa) from $P$. polymyxa MGL21, ${ }^{10)}$ but was the same as that of recombinant CFTase $(108 \mathrm{kDa})$ from the strain MGL21. ${ }^{11)}$ The enzyme was hardly inhibited by $\mathrm{Cu}^{2+}$ ion, which inhibited both the enzymes from B. circulans MCI-2554 ${ }^{7)}$ and B. macerans CFC1.' With respect to the enzymes from $P$. polymyxa MGL21, the $148 \mathrm{kDa}$ CFTase is reported to be inhibited by $\mathrm{Cu}^{2+}$ ion ${ }^{10)}$ whereas no inhibition was observed either in the $108 \mathrm{kDa}$ CFTase $^{11)}$ or the enzyme in this study. The most remarkable difference between this enzyme and the enzymes from B. circulans OKUMZ31B ${ }^{2)}$ B. circulans MCI-2554 ${ }^{7)}$ and B. macerans $\mathrm{CFC1}^{9)}$ was the production ratio of cycloinulohexaose $(\mathrm{CF}$ 6) and cycloinuloheptaose (CF7) as shown in Table 3, indicating that the enzyme from $P$. polymyxa MG-CF6 is capable of producing larger amounts of CF7 than the other enzymes. In this connection, crude enzyme prepared from culture broth of $P$. polymyxa MGL21 was found to produce CF6 and CF7 in a ratio of $2.7: 1,{ }^{10)}$ which was similar to that $(2.5: 1)$ in our purified enzyme.

$N$-Terminal amino acid sequence (DIKPDFK, amino acid position 253-259) of the purified enzyme was almost the same as that (TDIKPDFK, amino acid position 252259) of $137 \mathrm{kDa}$ CFTase from P. polymyxa MGL21, ${ }^{11}$ in which one more amino acid residue (Thr) is attached to the $N$-terminal amino acid of our purified enzyme. Unfortunately, You et al. ${ }^{11)}$ have reported that the $137 \mathrm{kDa}$ CFTase could not be purified because the strain MGL21 produced three CFTase with different molecular mass $(148,137$ and $108 \mathrm{kDa})$ and these enzymes could not be separated in any purification processes. However, taking into account the similarity of the $137 \mathrm{kDa}$ enzyme to our purified enzyme, it is considered that general properties of the $137 \mathrm{kDa}$ enzyme are highly analogous to those of our enzyme. In addition, since general properties of a recombinant $108 \mathrm{kDa}$ CFTase, ${ }^{11)}$ which was constructed by deleting a part of $N$-terminal polypeptide chain in the 137 $\mathrm{kDa}$ enzyme, were also very similar to those of our purified enzyme, $N$-terminal region of CFTase was thought 


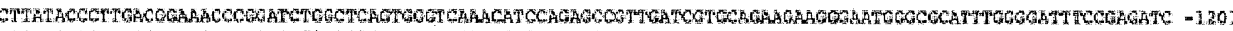

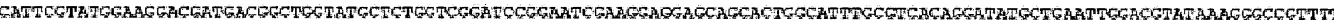
CATPAAG CaTMTr A TLAAAGEGATITT CAGAAGTH

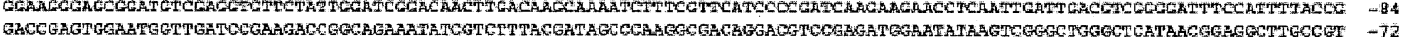

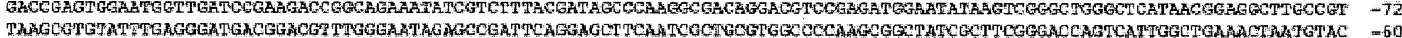

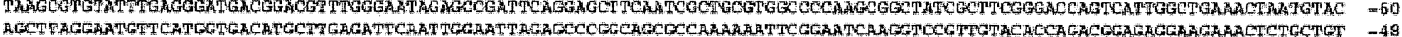

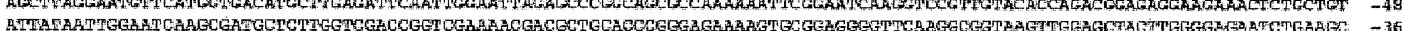

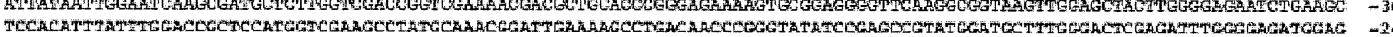

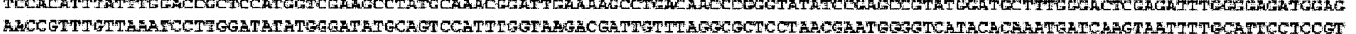

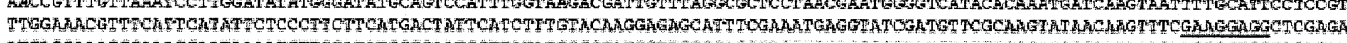

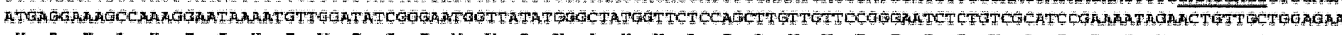

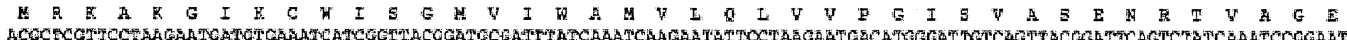

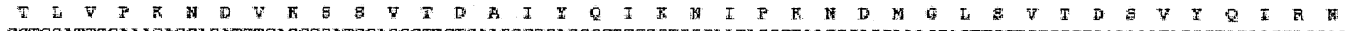

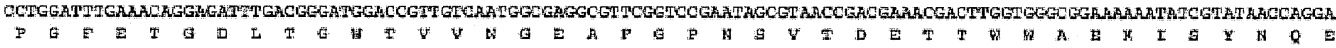
G A $\quad$ Y

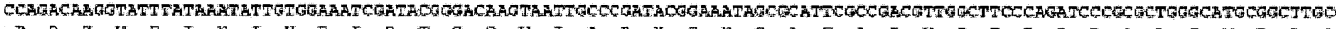

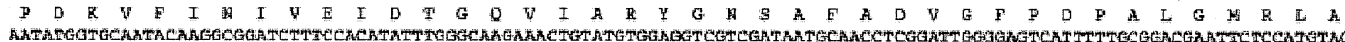

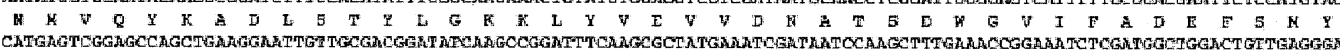

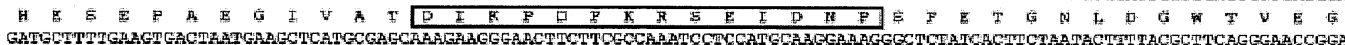

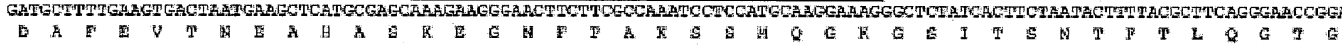

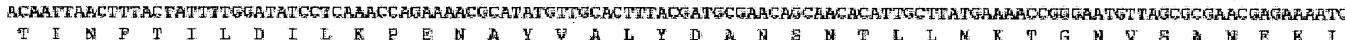

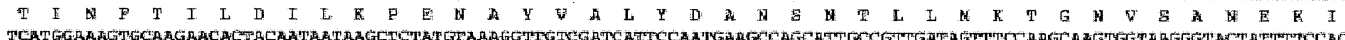

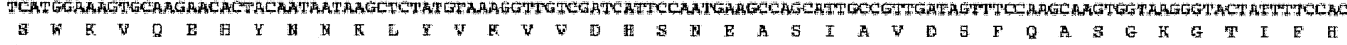

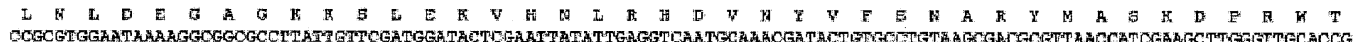

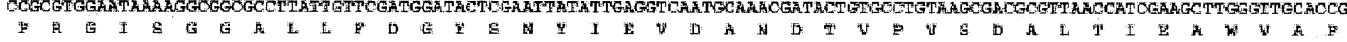

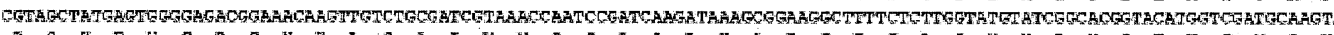

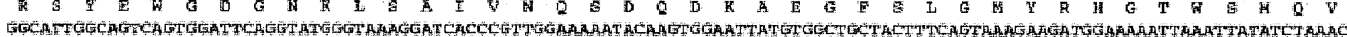
G I G E Q W I Q GETEAG

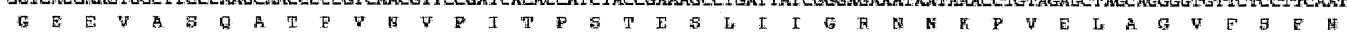
Th

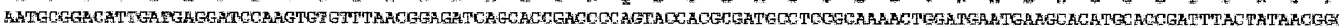
$\begin{array}{llllllllllllllllll} & \end{array}$

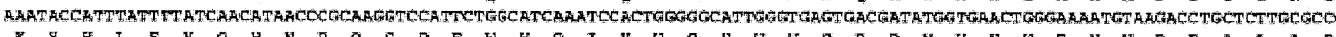

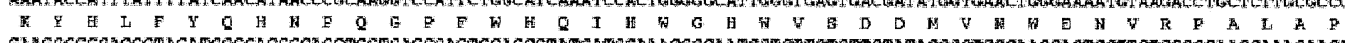

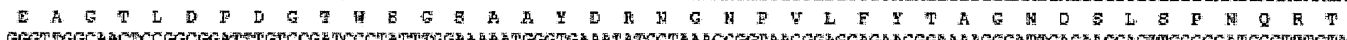

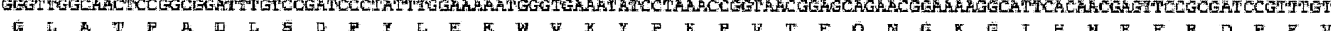

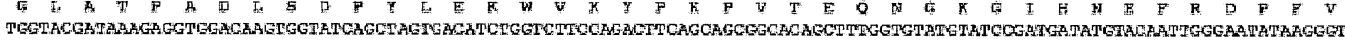

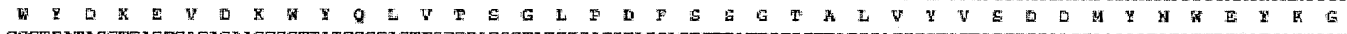

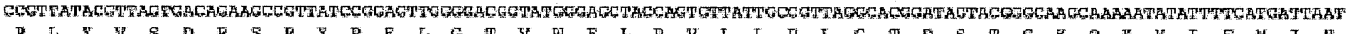

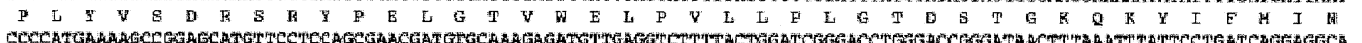

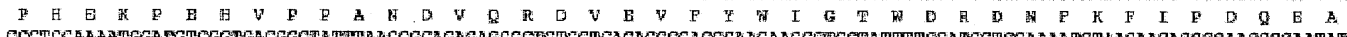

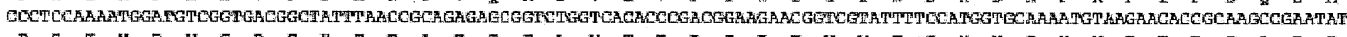

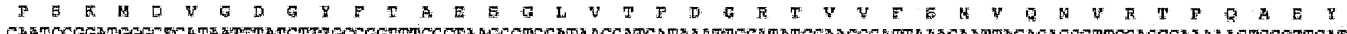

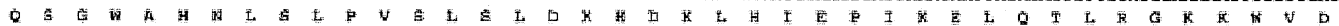

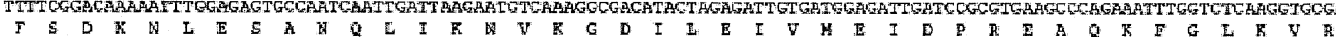

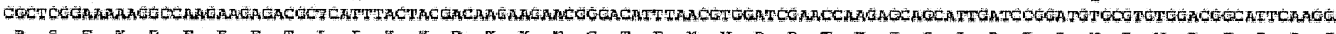

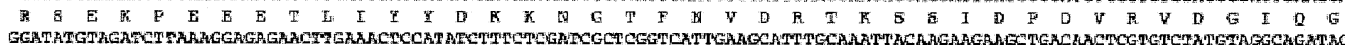

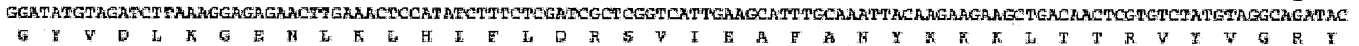

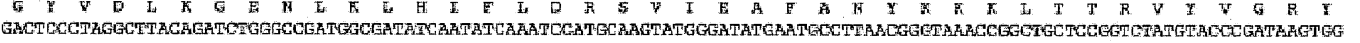

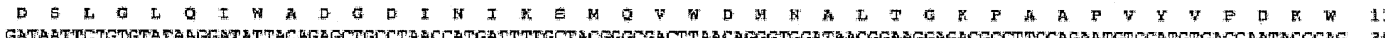

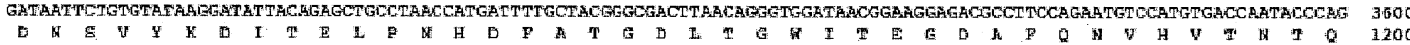

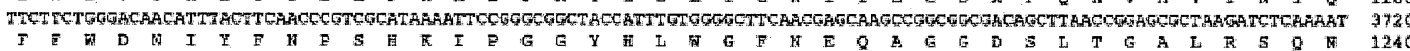

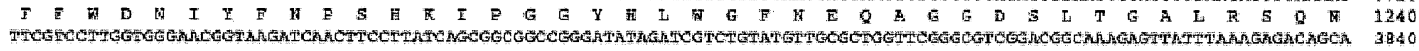
$\begin{array}{ccccccccccccccccc} & \end{array}$

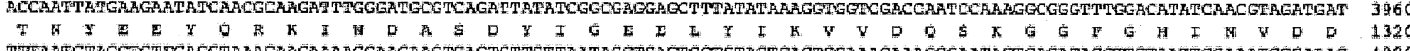

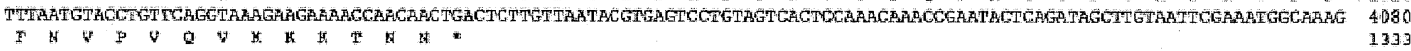

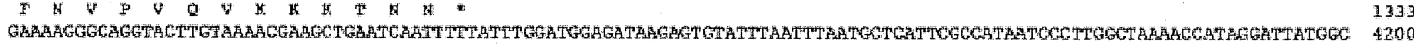

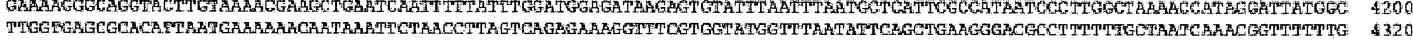

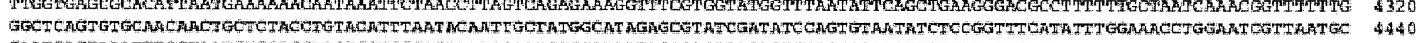

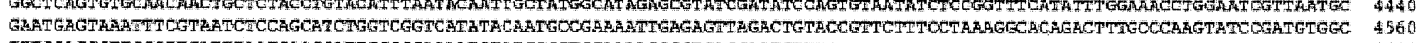

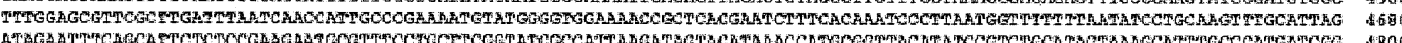

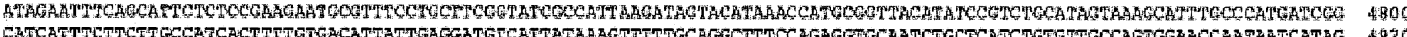

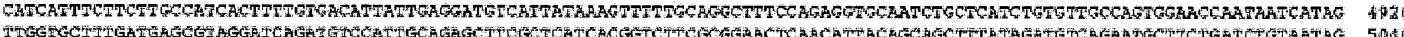

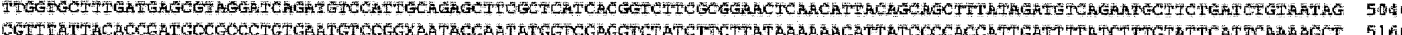

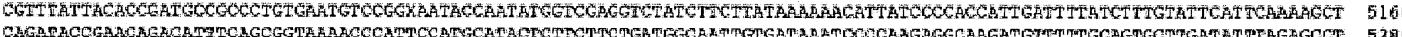

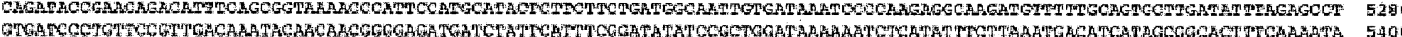

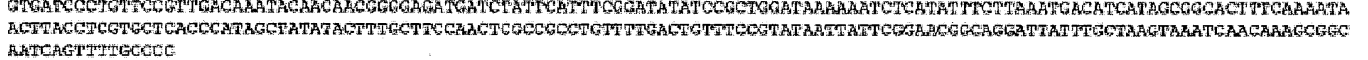

Fig. 2. Nucleotide sequence of CFTase gene and deduced amino acid sequence.

The deduced amino acid sequence of the CFTase is shown below the nucleotide sequence. The putative ribosome-binding site is indicated by an underline and the stop codon by an asterisk. The $N$-terminal amino acid sequence of the purified enzyme determined with an automated protein sequencer is boxed.

not to be important for the determination of enzymatic properties.

Deduced amino acid sequences of CFTases from $P$. polymyxa MGL2 $1^{10)}$ and from $B$. macerans $\mathrm{CFC1}^{9)}$ are reported to be divided into five distinct regions including three repeating regions (two regions exist $N$-terminus and one region $C$-terminus). The deduced amino acid se- quence of our enzyme had $98 \%$ and $95 \%$ similarity to that of the MGL21 and the B. macerans CFTases, respectively, and accordingly was regarded as being made up of the five distinct regions. On the other hand, in spite of high similarity of the amino acid sequence among the three CFTases as mentioned above, significant differences in the production ratio of $\mathrm{CF} 6$ and $\mathrm{CF} 7$ were observed as 


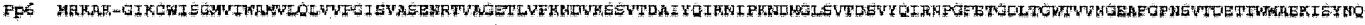

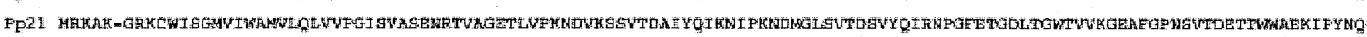

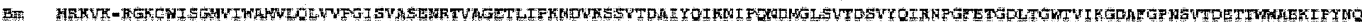

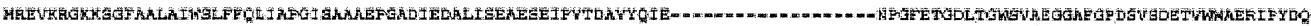

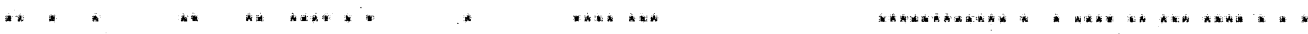

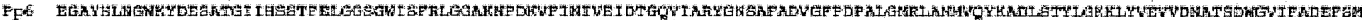

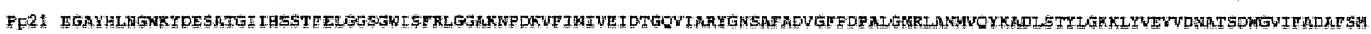

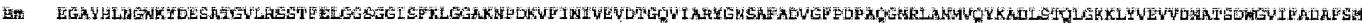

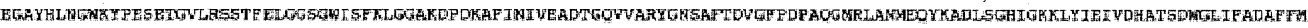
FEस

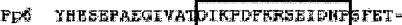

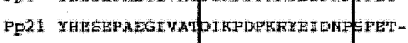

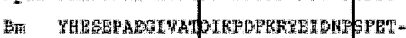

Be

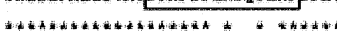

PES - -

PP21 - _ -

\$Fك R. R.

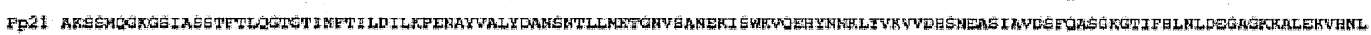

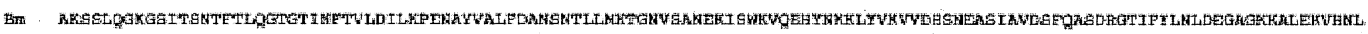

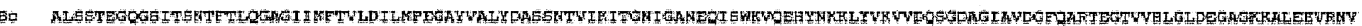

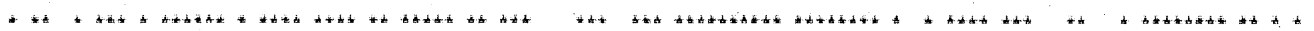

PF6 RAIVNAYYFE⿱

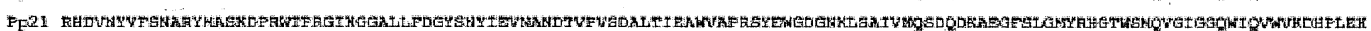

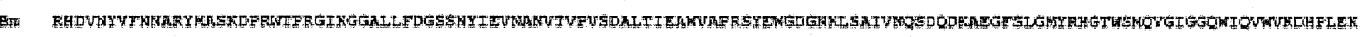

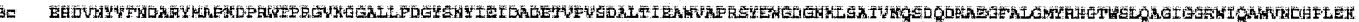

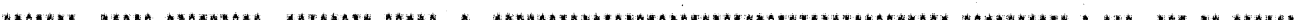

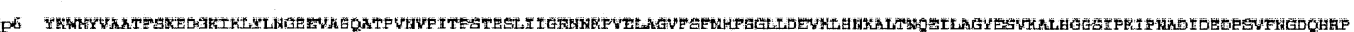

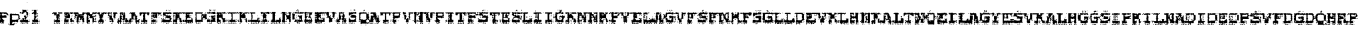

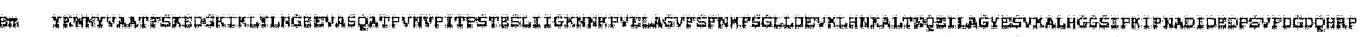

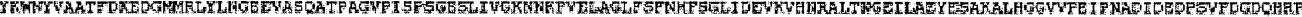

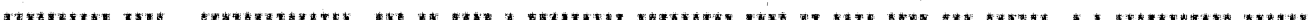

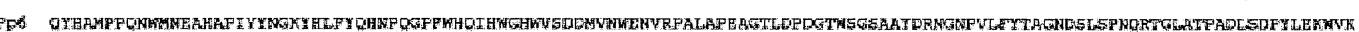

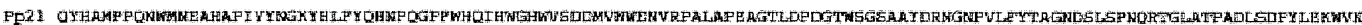

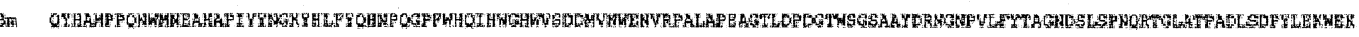

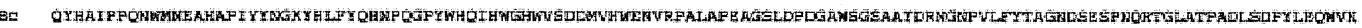

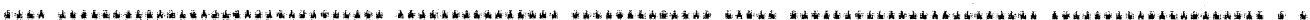

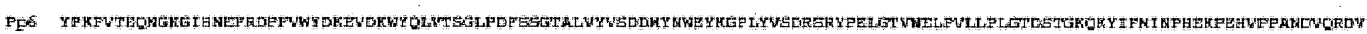

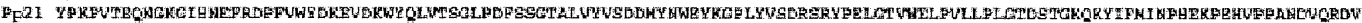

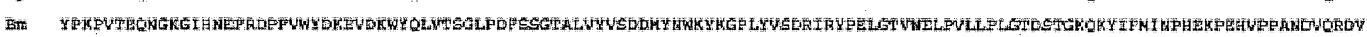

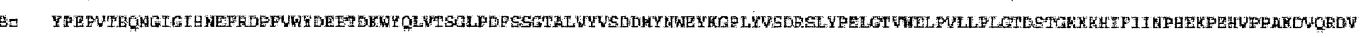

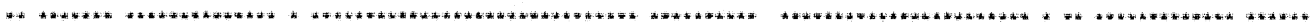

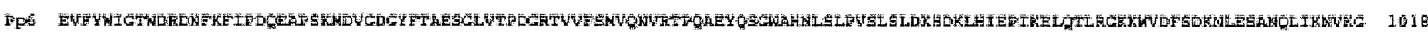

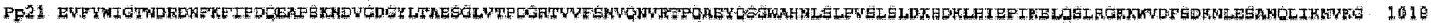

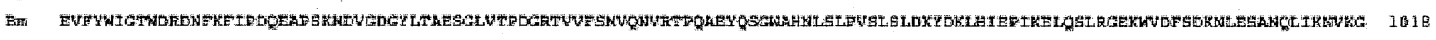

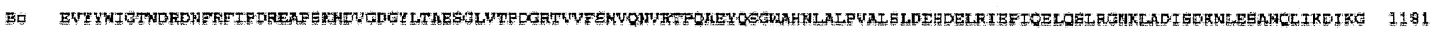

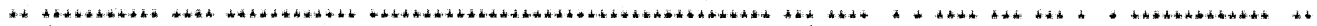

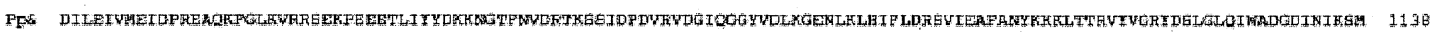

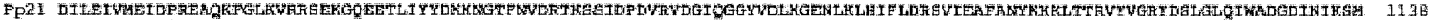

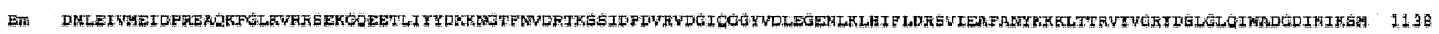

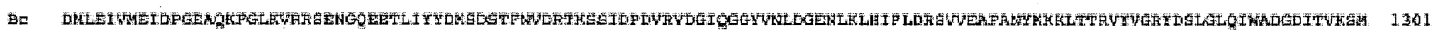
A

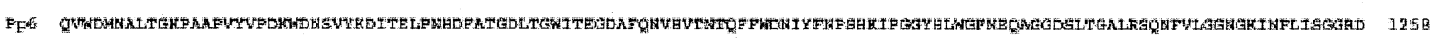

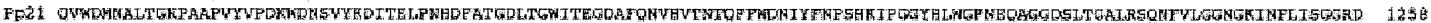

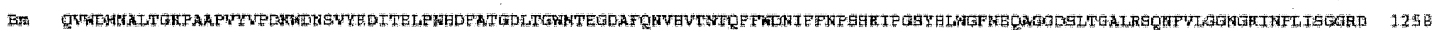

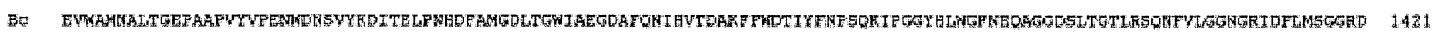

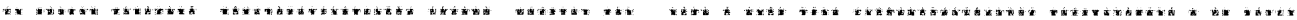

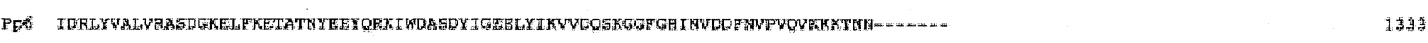

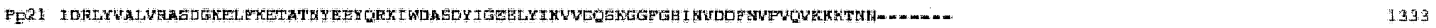

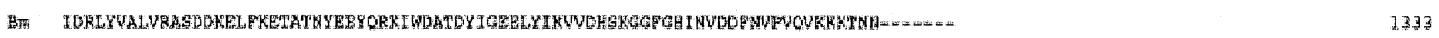

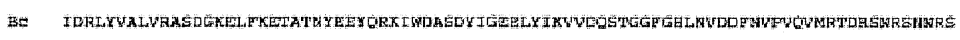
1333

Fig. 3. Alignment of amino acid sequence of CFTase.

Pp6, CFTase from P. polymyxa MG-CF6 (accession no. AB379660); Pp21, CFTase from P. polymyxa MGL21 (accession no. AY077612); Bm, CFTase from B. macerans CFC1 (accession no. AF222787); Bc, CFTase from B. circulans MCI-2554 (accession no. D87672). The asterisk indicates residues identical among the four sequences. The $N$-terminal amino acid sequences shown in Table 6 are boxed. The residue numbers of amino acids in each line are shown on the right.

indicated in Table 3. Namely, the production ratio of our purified enzyme was clearly distinct from that of the $B$. macerans CFTase, but was almost the same as the MGL 21 one. You et al. ${ }^{11)}$ have reported that $C$-terminal repeating region deleted enzymes of $P$. polymyxa MGL21 lose both CFTase and CF hydrolyzing activities while main- taining inulin hydrolyzing activity and thus, the substrate binding site for CF6 and CF7 formation exists in the $C$ terminal repeating region. Accordingly, we compared amino acid sequences in the $C$-terminal repeating region of the three enzymes. There was no difference in the sequences of the $C$-terminal region between the MG-CF6 
and MGL21 CFTases, but on the other hand, a relatively large difference (about 7\%) in the sequences of the $C$ terminal region was found as compared with the MG-CF6 and the $P$. macerans enzymes. From these findings, it may be reasonably supposed that the difference in the production ratio of CF6 and CF7 between our enzyme and the $P$. macerans enzyme is because of the different primary structures in the $C$-terminal polypeptide chain.

We wish to thank Dr. H. Kawagishi (Shizuoka University) for $\mathrm{N}$ terminal amino acid measurement. We also thank Ms. K. Wakabayashi in our laboratory for cultivation of bacterium.

\section{REFERENCES}

1 ) M. Kawamura, T. Uchiyama, T. Kuramoto, Y. Tamura and K. Mizutani: Formation of a cycloinuro-oligosaccharide from inulin by an extracellular enzyme of Bacillus circulans OKUMZ 31B. Carbohydr. Res., 192, 83-90 (1989).

2 ) M. Kawamura and T. Uchiyama: Purification and some properties of cycloinulo-oligosaccharide fructanotransferase from Bacillus circulans OKUMZ B31. Carbohydr. Res., 260, 297304 (1994).

3 ) M. Sawada, T. Tanaka, Y. Takai, T. Hanafusa, T. Taniguchi, M. Kawamura and T. Uchiyama: The crystal structure of cycloinulohexaose produced from inulin by cycloinulooligosaccharide fructanotransferase. Carbohydr. Res., 217, 717 (1991).

4 ) T. Uchiyama, M. Kawamura, T. Uragami and H. Okuno: Complexing of cycloinulo-oligosaccharides with metal ions. Carbohydr. Res., 241, 245-248 (1993).

5 ) K. Ozaki and M. Hayashi: Effect of cycloinulohexaose with additives on the freeze-drying of liposome. Int. J. Pharmaceutics, 160, 219-227 (1998).

6 ) S. Kushibe, R. Sashida and Y. Morimoto: Production of cyclofructan from inulin by Bacillus circulans MCI-2554. Biosci. Biotechnol. Biochem., 58, 1136-1138 (1994).

7 ) S. Kushibe, K. Mitsui, M. Yamagishi, K. Yamada and Y. Morimoto: Purification and characterization of cycloinulooligosaccharide fructanotransferase (CFTase) from Bacillus circulans MCI-2554. Biosci. Biotechnol. Biochem., 59, 31-34 (1995).

8 ) H.-Y. Kim, J.-B. Park, Y.-M. Kwon and Y.-J. Choi: Production of cycloinulooligosaccharide fructanotransferase (CFTase) from Bacillus sp. CFC1. J. Microbiol. Biotechnol., 6, 397-401 (1996).

9 ) H.-Y. Kim and Y.-J. Choi: Purification and characterization of cycloinulooligosaccaride fructanotransferase from Bacillus macerans CFC1. J. Microbiol. Biotechnol., 8, 251-257 (1998).

10) S.-J. Jeon, D.-J. You, H.-J. Kwon, S. Kanaya, N. Kunihiro, K.H. Kim, Y.-H. Kim and B.-W. Kim: Cloning and characterization of cycloinulooligosaccharide fructanotransferase (CFTase) from Bacillus polymyxa MGL21. J. Microbiol. Biotechnol., 12, 921-928 (2002).

11) D.-J. You, J.-H. Park, K.-O. You, S.-W. Nam, K.-H. Kim, B.W. Kim and H.-J. Kwon: Domain function and relevant enzyme activity of cycloinulooligosaccharide fructanotransferase from Paenibacillus polymyxa. Kor. J. Microbiol. Biotechnol., 34, 278-287 (2006)

12) T. Wada, M. Ohguchi and Y. Iwai: A novel enzyme of Bacillus sp. 217C-11 that produces inulin from sucrose. Biosci. Biotechnol. Biochem., 67, 1327-1334 (2003).

13) P.H.A. Sneath, N.S. Mair, M.E. Sharpe and J.G. Holt, ed.: Bergey's Manual of Systematic Bacteriology, Vol. 2, The Williams \& Wilkins Co., Baltimore, pp. 1104-1138 (1986).

14) K. Goto, T. Omura, Y. Hara and Y. Sadaie: Application of the partial $16 \mathrm{~S}$ rDNA sequence as an index for rapid identification of species in the genus Bacillus. J. Gen. Appl. Microbiol., 46, 1-8 (2000).

15) S.C. March, I. Parikh and P. Cuatrecasas: A simplified method for cyanogens bromide activation of agarose for affinity chromatography. Anal. Chem., 60, 149-152 (1989).

16) C.H. Lowry, N.J. Rosebrough, A.L. Farr and R.J. Randall: Protein measurement with the Folin phenol reagent. J. Biol. Chem., 193, 265-275 (1951).

17) H. Saito and K. Miura: Preparation of transforming deoxyribonucleic acid by phenol treatment. Biochim. Biophys. Acta, 72, 619-629 (1963).

18) T. Kanai, N. Ueki, T. Kawaguchi, Y. Teranishi, H. Atomi, C. Tomorbaatar, M. Ueda and A. Tanaka: Recombinant Thermostable cycloinulo-oligosaccharide fructanotransferase produced by Saccharomyces cerevisiae. Appl. Environ. Microbiol., 63, 4956-4960 (1997).

19) H.-Y. Kim and Y.-J. Choi: Molecular characterization of cycloinulooligosaccharide fructanotransferase from Bacillus macerans. Appl. Environ. Microbiol., 67, 995-1000 (2001).

\section{Paenibacillus polymyxa MG-CF6 の生産する シクロイヌロオリゴ糖生成酵素の精製と諸性質}

南条文雄 ${ }^{1}$, 御藤慶一 ${ }^{1}$, 岡ひと 及 $^{2}$, 村松久司 ${ }^{2}$ 加藤伸一郎 ${ }^{3}$, 永田信治 ${ }^{2}$ 1 三井農林株式会社食品総合研究所

(426-0133 藤枝市宮原 223-1)

2 高知大学農学部生物資源科学科

(783-8502 南国市物部乙 200)

3 高知大学総合研究センター

(783-8502 南国市物部乙 200)

シクロイヌロオリゴ糖生成酵素を生産する土塞細菌を 単離し Paenibacillus polymyxa MG-CF6 と同定した。本菌 株が生成するシクロイヌロオリゴ糖生成酵素を培養上清 液から SDS 電気泳動で単一バンドになるまで精製した。 本酵素の分子質量は $128 \mathrm{kDa}$ ，至適 $\mathrm{pH} 7.0$, 至適温度 $40^{\circ} \mathrm{C}$ であった。 また, 本酵素の $\mathrm{pH}$ 安定性は 6.0-9.0, 温度安 定性は $40^{\circ} \mathrm{C}$ 以下であった。本酵素は，シクロイヌロヘキ サオースとシクロイヌロヘプタオースを 2.5:1 の比率で生 成した。本酵素の $\mathrm{N}$-末端アミノ酸配列は，Bacillus macerans CFC1 およびBacillus polymyxa MGL21 の生産するシ クロイヌロオリゴ糖生成酵素のアミノ酸配列の一部分と 完全に一致した。さらに, 本酵素の遺伝子配列を解析し たところ，本酵素は 3999 のヌクレオチド配列にコードさ れた 1333 残基のアミノ酸からなるタンパク質であること が明らかになった。本酵素のアミノ酸配列を既知の酵素 のアミノ酸配列と比較したところ, 本酵素はBacillus circulans MCI-2554, Bacillus macerans CFC1 および Bacillus polymyxa MGL21 の生産するシクロイヌロオリゴ糖生成酵 素のアミノ酸配列とそれぞれ 83, 95 および $98 \%$ の相同 性を有することがわかった。 